\section{Study of Demineralized Dental Enamel Treated with Different Fluorinated Compounds by Raman Spectroscopy}

\author{
Barrera-Ortega C. C. ${ }^{1 * \odot}$, Vázquez-Olmos A. R. ${ }^{2}$, Sato-Berrú \\ R. Y. ${ }^{2}$, Araiza-Téllez M. A. ${ }^{3}$
}

\begin{abstract}
Background: Current diagnostic methods for enamel caries detection are unable to detect caries lesions (incipient caries lesion) at a very early stage.

Objective: This study aims to determine the remineralizing effect of three fluorinated compounds on demineralized subsurface tooth enamel using Raman spectroscopy characterization.
\end{abstract}

Material and Methods: In this experimental study, sixty impacted $3^{\text {rd }}$ molars, with intact anatomical crowns recently extracted and without structural defects, were sectioned longitudinally in a mesio-distal direction using a diamond disc, obtaining two working surfaces (buccal and lingual). The 120 working surfaces obtained were immersed for $96 \mathrm{~h}$ in a demineralization solution at $37^{\circ} \mathrm{C}$ in order to demineralize the enamel surface. All samples were randomly divided into three groups ( $\mathrm{n}=30$ each) and their surfaces were treated with silver diamine fluoride (SDF), Difluoride silane (DSF), and acidulated phosphate fluoride (APF), and with no treatment undertaken in the control group (CG). The samples were immersed in alternating solutions for demineralization and remineralization at $\mathrm{pH} 4.4$ and $\mathrm{pH} 7.0$, respectively. The results were analyzed with Principal Component Analysis (PCA) in order to determine the variance.

Results: The most important difference (91.7\%) is observed in APF group between PCA1 respect to PCA2, followed by DSF (91.5\%) and SDF (76.3\%) respectively. Therefore, a greater remineralization in the dental enamel can be observed by the three experimental groups.

Conclusion: The APF and DSF have the effect of recovering the mineralization of dental enamel, except for the SDF. Functional groups $\mathrm{OH}^{-}$and $\mathrm{PO}_{4}{ }^{3-}$ were identified in all subsurface.

Citation: Barrera-Ortega CC, Vázquez-Olmos AR, Sato-Berrú RY, Araiza-Téllez MA. Study of Demineralized Dental Enamel Treated with Different Fluorinated Compounds by Raman Spectroscopy. J Biomed Phys Eng. 2020;10(5):635-644. doi: 10.31661/jbpe.v0i0.2003-1089.

\section{Keywords}

Tooth Remineralization; Dental Enamel; Raman Spectroscopy; Fluorine Compounds, Tooth Demineralization

\section{Introduction}

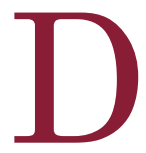
ental enamel is the hardest and most highly mineralized tissue of the human body, which contains more than $95 \%$ of carbonated hydroxyapatite and less than $1 \%$ of organic matter. As a highly mineralized tissue, enamel can withstand a wide range of functional and non-functional loads and protect the underlying dentin from directly ex-
${ }^{1} \mathrm{PhD}$, Coordinator Paediatric Stomatology

Specialties. Iztacala

Faculty of Higher Studies

(FESI), National Au-

tonomous University of

Mexico (UNAM), State of

Mexico, Mexico. Avenida

de los Barrios No. 1 Col.

Los Reyes Ixtacala Tlal-

nepantla de Baz, Estado

de México CP. 54090.

Mexico

${ }^{2} \mathrm{PhD}$, Institute of Applied and Technological Sci-

ences, National Au-

tonomous University of

Mexico (UNAM), Circuito

Exterior S/N C.P. 04510

Cd. Universitaria, Ciudad

de México

${ }^{3} \mathrm{PhD}$, Dental Materials

Laboratory, Division of

Postgraduate Studies

and Research of the

Faculty of Dentistry,

National Autonomous

University of Mexico

(UNAM), Circuito Institu-

tos S/N Ciudad Univer-

sitaria, Colonia Copilco

Universidad, Delegación

Coyoacán, México Dis-

trito Federal, C.P

*Corresponding author:

C. C. Barrera-Ortega

Coordinator Paediatric

Stomatology Special-

ties. Iztacala Faculty of

Higher Studies (FESI),

National Autonomous

University of Mexico

(UNAM), State of Mexico,

Mexico. Avenida de los

Barrios No. 1 Col. Los

Reyes Ixtacala Tlal-

nepantla de Baz, Estado

de México CP. 54090.

Mexico. 525518119403

E-mail: cbarrera@unam.

$\mathrm{mx}$

Received: 25 March 2020

Accepted: 6 May 2020 
posing to the harsh oral environment [1].

The Fluoride ion $\left(\mathrm{F}^{-}\right)$has great chemical activity, and also can be combined with any element as well as organic radicals. In nature, $\mathrm{F}^{-}$ can be found in different minerals as fluorite, cryolite and apatite. In biological systems, the presence of fluoride during the mineralization process causes abnormalities in the crystal development of inorganic phases on bones and teeth, modifying the chemical structure into fluoridated hydroxyapatite $\mathrm{Ca}_{10}\left(\mathrm{PO}_{4}\right)_{6}(\mathrm{OH})_{2}{ }^{-} \mathrm{F}_{2}$ $[2,3]$. In preventive dentistry, fluoride is applied to the outer surface of the dental enamel to prevent the development of carious lesions. The use of fluoride benefits has been overstated without discussing, the differences among concentrations and type of vehicle (gel, varnish, and solution) because they are the most commonly used in paediatric dental practice $[4,5]$.

On the other hand, Raman spectroscopy actually offers the possibility to obtain information on the chemical structural organization of enamel $[6,7]$. This is a non-destructive technique used to characterize organic and inorganic compounds through the identification of characteristic vibration modes [8,9]. A great variety of biological samples has been studied at the Raman spectroscopy $[9,10]$ as in the case of the hydroxyapatite (HA), dentin and enamel [11, 12] using a focused laser beam; the identification of hydroxyl group in bone, the possible incorporation of halogens in the hydroxyapatite structure, has a direct implication in the physical and chemical properties in permeability of the dental enamel. In clinical dentistry, the use of fluorinated compound as a preventive action is a recognized practice because it can increase resistance to the caries process by incorporating fluoride ions into the molecular structure of hydroxyapatite. There has been reported a variety of vehicles used to apply the fluoride compounds as the solution of Silver Diamine Fluoride, $\mathrm{Ag}\left(\mathrm{NH}_{3}\right)_{2} \mathrm{~F}$ (SDF) with 44.800 parts per million of $\mathrm{F}^{-}$and $38 \%$ of silver, with $\mathrm{pH}=13$ [11-13], varnish of Di-
Fluoride Silane with 1000 parts per million of $\mathrm{F}^{-}, 1 \%$ di-fluor-silane (DSF) in a polyurethane lacquer for Fluor-Protector [14, 15] and gel of acidulated phosphate fluoride (APF) with 12.300 parts per million $\mathrm{F}^{-} 1.23 \%$ with $\mathrm{pH}=3.5$ for Topex 60-Sultan [16]. Based on p rincipal component analysis (PCA) to Raman signal of $\mathrm{OH}^{-}$and $\mathrm{PO}_{4}{ }^{3-}$ carried out,

PCA is mainly a classification (non-parametric statistical) method of spectral data, aiming to reduce the data dimensions of highly complex systems to the smaller number subset for determine the most important spectra information. This method generated a new set of orthogonal variables, called principal components (PCs). The first principal component (PC1) is a single axis in space and the second principal component (PC2) is another axis in space, perpendicular to the first. The full set of PCs is as large as the original set of variables. It is common place for the sum of the variances of the first few PCs to exceed $80 \%$ of the total variance of the original data [17].

\section{Material and Methods}

\section{Specimens and Preparation of Sam- ple Group}

In this experimental study, sixty molars studied here were obtained from patients attending the eight outlying clinics of the faculty of Higher Education Iztacala in the University National Autonomous of Mexico (UNAM) and who had been collected for maxillofacial surgery by clinical professors at the clinics. The use of these molars in this study was approved by the faculty's Ethics Committee (EC/FESI/062019/1307) and was conducted in accordance with the Helsinki Declaration of the World Medical Association. All the third molars were obtained over a period of three months. Informed consent was obtained from patients undergoing dental surgery procedures, all of whom were between 17 and 22-year-old.

Periodontal debris was removed prior to the tooth sectioned with the molars then stored 
Raman Spectroscopy on Enamel Remineralized

in deionized water until the experimental tests were performed. In accordance with ten Cate $[18,19]$, soft tissues were removed from radicular surface and a dental cleaning was made with a prophylactic paste free for fluoride $\left(\mathrm{QOM}^{\mathrm{TM}}\right.$ Mexico). Then, they were longitudinally sectioned with a diamond disc (Brassler ${ }^{\mathrm{TM}}$ diamond) under constant irrigation, after which the 64 working surfaces obtained were filled with pink wax in the internal area of the tooth (the pulp chamber and the root canals) in order to obtain a smooth surface. After which a working area was created by covering the root and crown with acidresistant varnish (Revlon ${ }^{\mathrm{TM}}$ different colors, New York, U.S.), leaving a $3 \times 6 \mathrm{~mm}$ area at the center of the lingual or buccal surface of the crown [20].

\section{Demineralized Lesion (initial le- sion)}

Ten Cate JM et al., designed a $\mathrm{pH}$ cycling model to study mineral loss and gain in artificial enamel lesions, generating a model which is the best reproduction in vivo conditions. As the work surfaces were healthy, initial lesions were made with demineralizing solution, after which 120 work surfaces (buccal and lingual faces) were immersed in a demineralizing solution $\left(2.2 \mathrm{mM} \mathrm{CaCl}_{2}, 2.2 \mathrm{mM} \mathrm{NaH}_{2} \mathrm{PO}_{4}\right.$, and $0.05 \mathrm{M}$ acetic acid) for $96 \mathrm{~h}$ at $37^{\circ} \mathrm{C}$ [14], while the $\mathrm{pH}$ was adjusted using a solution buffer, to 4.4 with $1 \mathrm{M} \mathrm{KOH} \mathrm{[14].} \mathrm{Once} \mathrm{the}$ $96 \mathrm{~h}$ had elapsed, all demineralized surfaces were randomised and experimental groups were formed to receive the indicated treatment: group I- SDF $(n=30)$ (SDF-Saforide $\left.{ }^{\mathrm{TM}}\right)$, group II- DSF $(n=30)$ (DSF-Fluor Protector $^{\mathrm{TM}}$ ), group III- APF ( $\left.\mathrm{n}=30\right)$ (APF-SultanHealth $^{\mathrm{TM}}$ ), and group IV- Control Group (CG) $(n=30)$, which received no treatment.

The following treatment process was applied:

1. The surfaces of the tooth were removed from demineralizing solution.

2. All work surfaces were rinsed with deion- ized water.

3. The fluoride compounds were placed on each surface using their respective brush.

4. The fluorinated compound was left on the work surfaces for $60 \mathrm{~s}$, with the time taken on a stopwatch, in accordance with the manufacturer's instructions.

5. Once the time had elapsed, the sample was placed in there mineralizing solution in order to continue the $\mathrm{pH}$ cycling.

The $\mathrm{pH}$ cycling sequence is given as follows:

a) $21 \mathrm{~h}$ in remineralizing solution $(1.5 \mathrm{mM}$ $\mathrm{CaCl}_{2}, 0.9 \mathrm{mM} \mathrm{NaH} \mathrm{PO}_{4}$ and $0.15 \mathrm{mM} \mathrm{KCl}$ ) with the $\mathrm{pH}$ adjusted, with a buffer solution, to 7.0 with a $1 \mathrm{M} \mathrm{KOH}$ solution.

b) $3 \mathrm{~h}$ in demineralizing solution $(2.2 \mathrm{mM}$ of $\mathrm{Ca}, 2.2 \mathrm{mM}$ of $\mathrm{P}$, and $5.0 \mathrm{mM}$ of $\mathrm{CH}_{3} \mathrm{COOH}$ ) with a $\mathrm{pH}$ of 4.4 .

The fluorinated compound application of (DSF, SDF or APF) was of 60-second. Between the application of the demineralizing and remineralizing solutions, the working surface was rinsed with deionized water. The composition of the demineralizing solution was $2.2 \mathrm{mM}$ of $\mathrm{Ca}, 2.2 \mathrm{mM}$ of $\mathrm{P}$, and $5.0 \mathrm{mM}$ of $\mathrm{CH}_{3} \mathrm{COOH}$ [21], with a $\mathrm{pH}$ of 4.4 , while the composition of the remineralizing solution was $1.5 \mathrm{mM}$ of $\mathrm{CaCl}_{2}, 0.9 \mathrm{mM}$ of $\mathrm{NaH}_{2} \mathrm{PO}_{4}$ and $0.15 \mathrm{mM}$ of $\mathrm{KCl}$, with the $\mathrm{pH}$ adjusted with a buffer solution to 7.0 with a $1 \mathrm{M} \mathrm{KOH}$ solution. The solutions were prepared every third day. After 5, 10 and 15 days, the $\mathrm{pH}$ cycling solutions [22] (those used for both remineralization and demineralization) were removed from the working surfaces to enable the Vickers microhardness tests. Before the microhardness test was performed, the surfaces were immersed in deionized water at $37^{\circ} \mathrm{C}$ [23].

However, to date, these three fluorinated compounds have not been compared in the literature i.e. on subsurface human dental enamel at different depths with different vehicles: gel, solution and varnish, all of them used currently in pediatric dentistry. In this work, the effect of three different fluoride compounds (gel, vanish, and solution) on the surface of 
dental enamel at cycling $\mathrm{pH}$ conditions was study by Raman spectroscopy. Functional hydroxyl $\left(\mathrm{OH}^{-}\right)$and phosphate $\left(\mathrm{PO}_{4}^{3-}\right)$ groups were identified. Tetrahedral $\left(\mathrm{PO}_{4}^{3-}\right)$ group is representative of the mineral phase (carbonated hydroxyapatite) in teeth when the remineralization is carried out. Raman spectroscopy as a non-destructive technique allowed us to analyze samples before and after applying the fluorinated compounds being a very suitable.

\section{Cycling $\mathrm{pH}$}

The sequence of $\mathrm{pH}$ cycling was daily repeated, and 10 samples of each experimental groups were removed at 5, 10 and 15 days and among the different depths $(50,100$ y $150 \mathrm{mi}-$ crons). After this, samples were longitudinally sectioned at vestibular-lingual orientation and mounted in acrylic resin.

\section{Statistical Analysis}

10 spectra were taken from each group, including CG, DSF, SDF and APF. Each acquired spectrum was normalized to the highest peak. All spectra were processed by carrying baseline correction, smoothing, and normalization to remove noise, fluorescence, and shot noise from cosmic rays, through a filter based on the baseline correction with asymmetric least squares smoothing algorithm. After the initial processing, the spectrum mean of each group was calculated. The mean spectra were analyzed to obtain general molecular information for each data group [24-26]. Once the spectra were processed, PCA was implemented, where the main information is described by the first principal components. PCA through its score plot allows all samples (which appear as individual points on the plot) to be assessed for similarities and differences using the principal component scores associated with the samples, in this case, principal component 1 (PCA1) and principal component 2 (PCA2). The "closeness" of PC scores of two samples indicates the behavior of the different fluorinated compounds which are similar and vice versa [27]. The obtained Raman spectra $(\mathrm{N}=490)$ were analyzed using the MATLAB $^{\text {TM }}$ R2010 software in order to determine the variance of PCA [24].

\section{Results}

\section{Raman spectroscopy}

All spectra were collected at a Nicolet, Almega-XR TM Raman System with Nd:YVO4 laser beam at $532 \mathrm{~nm}$ in the 400 to $4000 \mathrm{~cm}^{-1}$ range [28]. Raman spectra were obtained at 50,100 and 150 microns from the dental enamel subsurface to the enamel-dentine junction, and 10 spectra were generated for each deep in Figure 1.

The mean Raman spectrum for dental enamel and hydroxyapatite, in these spectra the characteristic vibration of phosphate ions was observed Figure 2 shows. Oxygen shifts with phosphorus at the same time $\left(\mathrm{PO}_{4}{ }^{3-}\right)$, peak at $970 \mathrm{~cm}^{-1}$, and the group $\mathrm{OH}^{-}$associated with the peak of $3621 \mathrm{~cm}^{-1}$. It was also observed that the intensity of the band at $970 \mathrm{~cm}^{-1}$ associated with the frequency of vibration of $\mathrm{PO}_{4}^{3-}$ group, increases as the $\mathrm{OH}^{-}$group increases [29].

The experimental group treated with DSF shows the characteristic vibrations bands of the functional groups $\left(\mathrm{PO}_{4}{ }^{3-}\right.$ and $\left.\mathrm{OH}^{-}\right)$in samples obtaining at different days in different depths has been illustrated in Figure 3. It should be noted that on $15^{\text {th }}$ day of treatment, the peak due to the $\mathrm{PO}_{4}^{3-}\left(970 \mathrm{~cm}^{-1}\right)$ shows a greater expression.

Representative Raman spectra of the experimental group APF are shown in Figure 4. Both $\mathrm{PO}_{4}^{3-}\left(970 \mathrm{~cm}^{-1}\right)$ and $\mathrm{OH}^{-}\left(3621 \mathrm{~cm}^{-1}\right)$ groups are observed at different treatment days and different depths.

In the experimental group treated with SDF (Figure 5), the characteristic signals of the functional groups were observed at the different days of treatment. However, the most representative peak was observed after 5 days, at 50 microns of deep. 


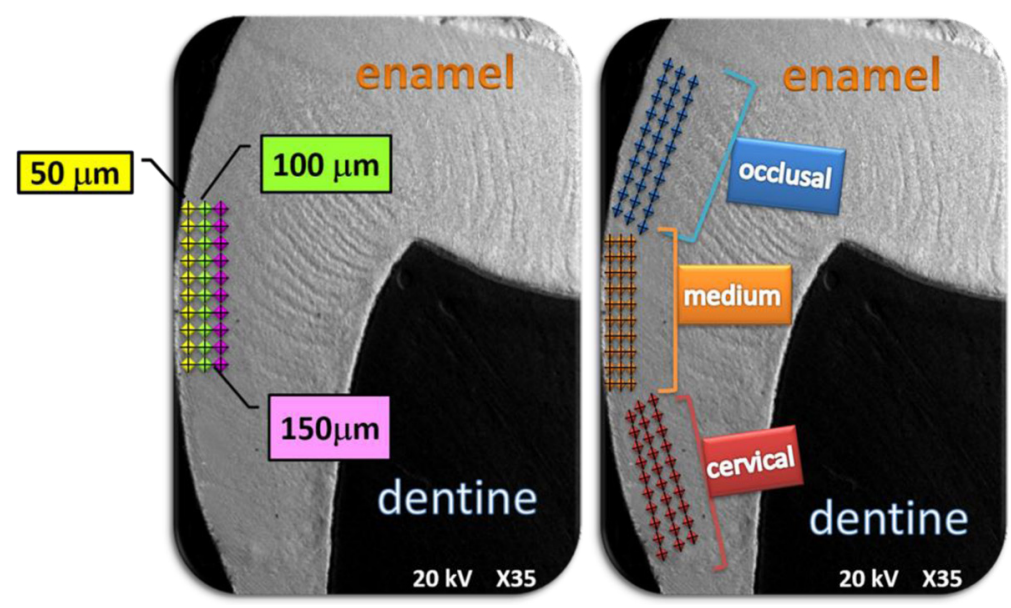

Figure 1: Scanning Electron Microscope (SEM) micrograph of the tooth enamel subsurface, showing the different depths (50,100 and 150 microns) and the location (occlusal, medium and cervical) where Raman spectroscopy was used to detect the different functional groups.

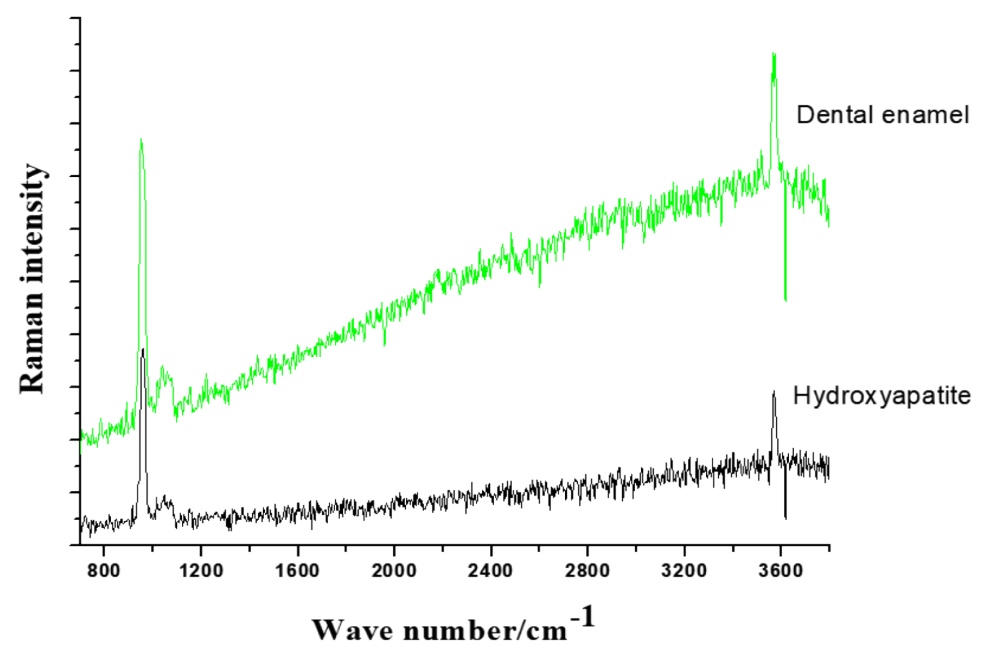

Figure 2: The Raman spectra of dental enamel and hydroxyapatite (HA) reference where a characteristic vibration mode of $\mathrm{PO}_{4}^{3-}$ at $970 \mathrm{~cm}^{-1}$ and $\mathrm{OH}^{-}$at $3621 \mathrm{~cm}^{-1}$ are observed.

With regard to the control group, i.e. the group not being treated, the $\mathrm{OH}^{-}$group is not observed at $5^{\text {th }}$ and $15^{\text {th }}$ days of treatment. At 10 days it is observed lightly to the symmetric stretching vibration $\mathrm{P}-\mathrm{O}$ of phosphate ions, nevertheless, the peaks corresponding to the $\mathrm{PO}_{4}^{3-}\left(970 \mathrm{~cm}^{-1}\right)$ group are not observed at 5 and 15 days after ph cycling, has been illustrated in Figure 6, since the peaks corresponding to the functional groups are not observed, we can conclude that there is demineralization of dental enamel.

\section{Results PCA}

In the present study, the spectra of DSF, APF, SDF were analyzed by PCA, in the weights of the main components of the experimental group DSF, they are concentrated near the axes PCA1 y PCA2. Likewise, the group treated with DSF had a PCA1 of $91.5 \%$ vs PCA2 of 


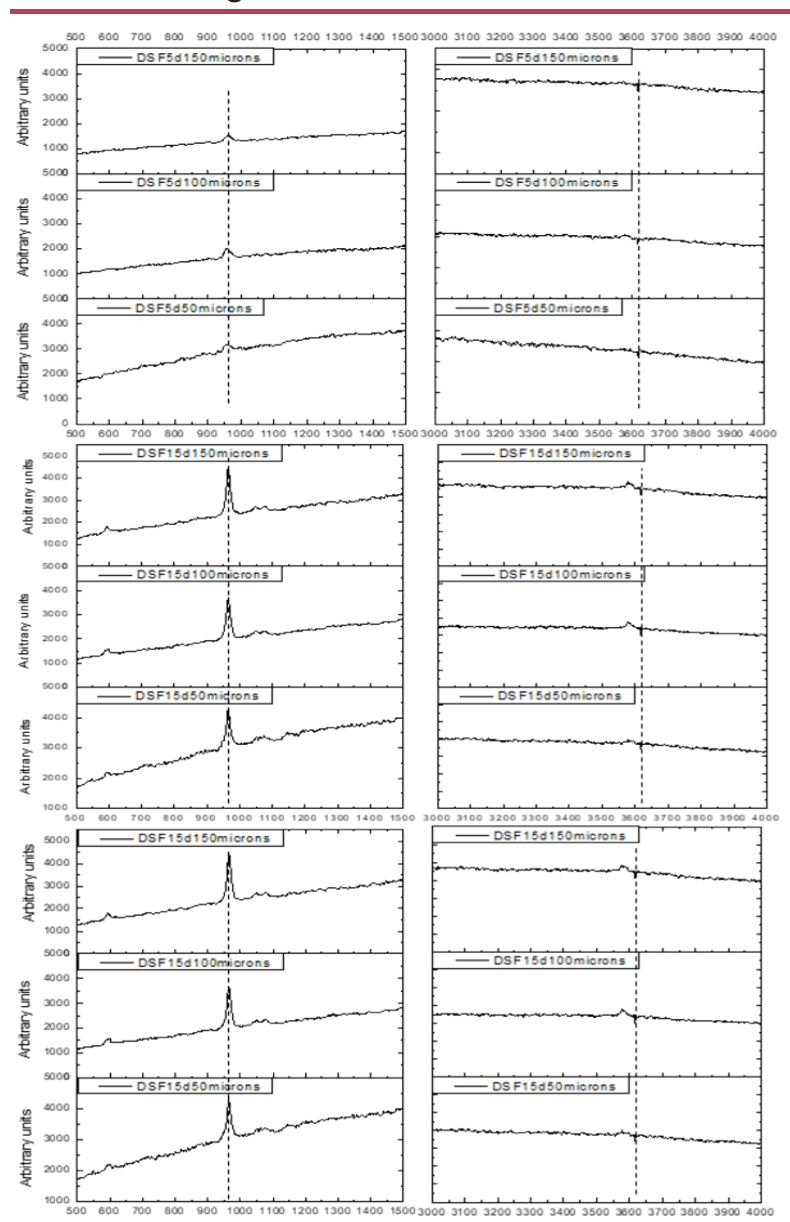

Figure 3: Representative spectra of the experimental group treated with Difluoride silane (DSF) at $5^{\text {th }}, 10^{\text {th }}$ and $15^{\text {th }}$ days and at 50 , 100 and 150 microns deep (dentin enamel junction) were observed and the peaks due to $\mathrm{PO}_{4}^{3-}\left(970 \mathrm{~cm}^{-1}\right)$ and the $\mathrm{OH}^{-}\left(3621 \mathrm{~cm}^{-1}\right)$ groups. The greater distance from the dental surface, the greater the intensity of the $\mathrm{PO}_{4}{ }^{3-}$ group.

$8.16 \%$. Moreover, the DSF compound is closer to the dental enamel and therefore produces greater topical remineralization since a greater concentration of the DSF points is very close to the points of the dental enamel and those of the control group are more dispersed as seen in Figure 7A.

The group treated with APF had a PCA1 of $91.67 \%$ vs. PCA2 of $7.95 \%$, as well as the DSF group. the APF compound is closer to the dental enamel and therefore produces a greater
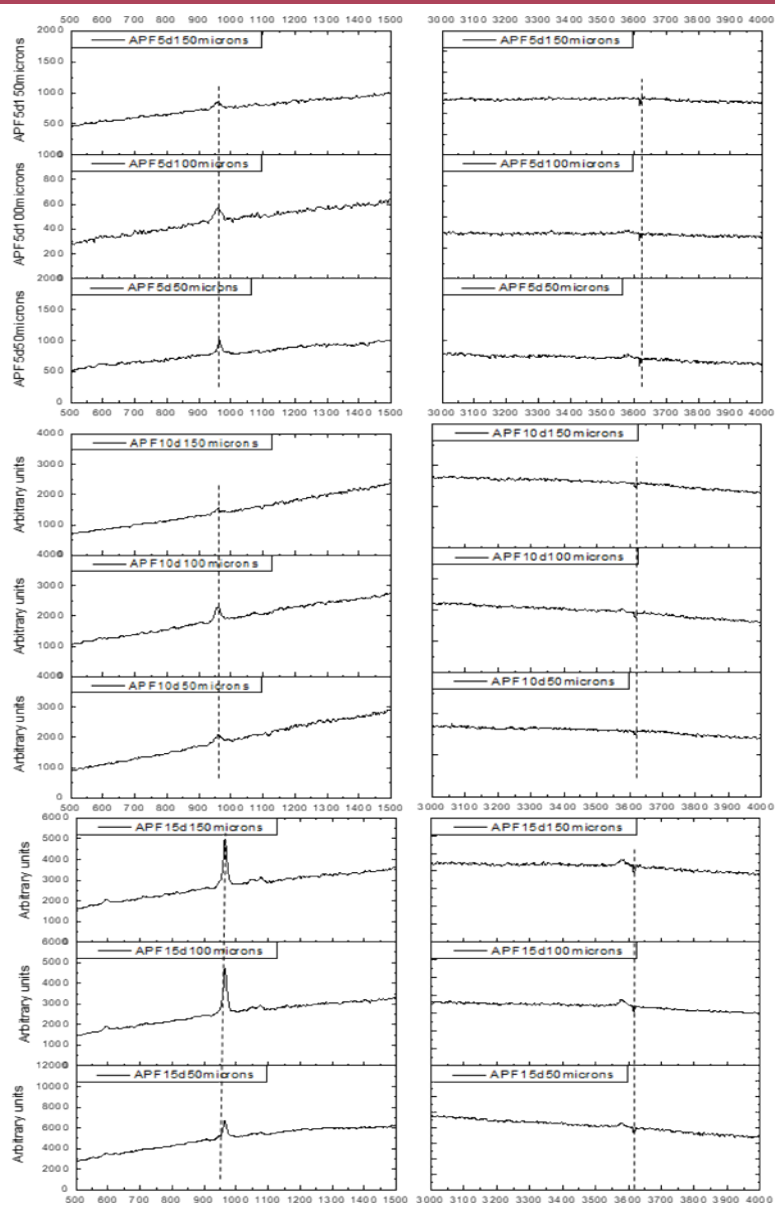

Figure 4: Representative Raman spectra of the experimental group treated with acidulated phosphate fluoride (APF) at $5^{\text {th }}, 10^{\text {th }}$ and $15^{\text {th }}$ days and at 50, 100 and $150 \mathrm{mi}$ crons deep (dentin enamel junction) were observed; the representative peaks of the functional group $\mathrm{PO}_{4}^{3-}\left(970 \mathrm{~cm}^{-1}\right)$ and the $\mathrm{OH}^{-}$ group $\left(3621 \mathrm{~cm}^{-1}\right)$ were observed as well.

topical remineralization since it is possible to observe a concentration of the APF points near the points of the dental enamel although there is a slight dispersion in them and those of the control group are more dispersed as seen in Figure 7B.

The group treated with SDF had a PCA1 of $76.34 \%$ vs PCA2 of $19.25 \%$, in all its observations presented a behavior different from the control group, therefore the SDF compound has greater dispersion on the dental enamel 
Raman Spectroscopy on Enamel Remineralized

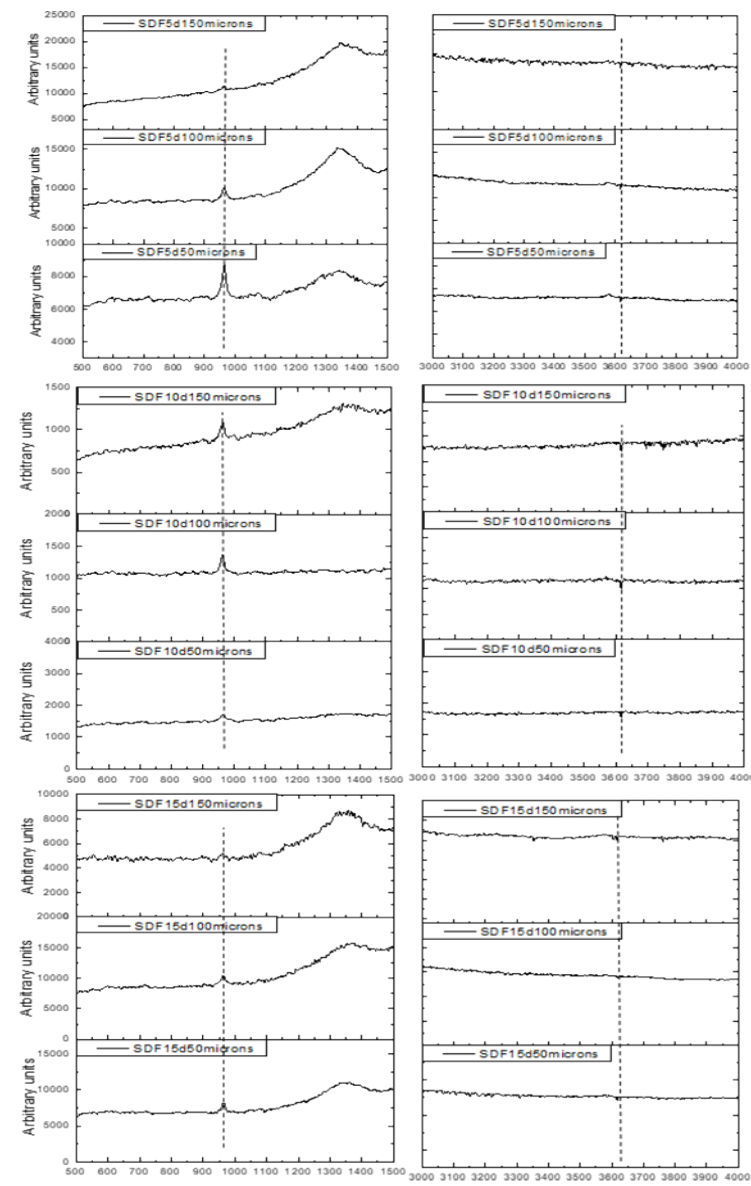

Figure 5: Representative spectra of the experimental group treated with Silver Diamine Fluoride (SDF) at $5^{\text {th }} 10^{\text {th }}$ and $15^{\text {th }}$ days and at 50, 100 and 150 microns deep (dentin enamel junction) were observed and the peaks of the $\mathrm{PO}_{4}^{3-}\left(970 \mathrm{~cm}^{-1}\right)$ and the $\mathrm{OH}^{-}$ $\left(3621 \mathrm{~cm}^{-1}\right)$ groups.

and therefore the topical remineralization could be minor since in Figure $7 \mathrm{C}$ a lower concentration of SDF points can be observed near the points of the dental enamel.

\section{Discussion}

Raman spectroscopy is a technique used for the analysis of the molecular composition of dental enamel. It is an effective technique to analyze the inorganic surface tissue since it is possible to obtain information about the minerals (functional groups) present through the vibrational spectra. In the present study it was found that the PCA has a better discrimination between the experimental and control groups since according to the results, it was found that for the DSF group it had a discrimination of 91.5\%, APF 91.67\% and SDF 76.34\%.

Moreover, it was observed that the three fluorinated compounds (DSF, APF and SDF) produce the greatest remineralization on the enamel surface. Also, the remineralization of the enamel surface will depend on the bioavailability of the fluoride ions on the surface of the tooth [30]. In addition, fluoride reduces demineralization and increases the remineralization of the surface of the tooth enamel [30-32]. Several investigations have shown the effect that remineralizers have on dental enamel $[33,34]$. Yu OY et al., reported that the application of DSF decreased the demineralization of caries lesions and also inhibited the growth of the biofilm [35]. Likewise Jardim JJ et al., found that three or more applications of APF improve hardening and there is a higher concentration of fluoride in the dental enamel [36].

PCA analysis for Raman spectroscopy has the potential to be a non-invasive real-time tool for the early detection and monitoring evolution of dental. It requires no sample preparation and provides objective, specific, and fast results, reducing subjectivity to human error [24] for that reason in this investigation, Raman spectroscopy and principal component analysis were used.

González-Solis et al., [24] demonstrated that Raman spectroscopy and analysis of the principal components can be used to discriminate in experiments with human molars (tooth enamel), healthy tooth with healthy enamel, severe dental fluorosis, hard samples with high sensitivity and specificity. In this study, only the effect of three different fluorinated compounds with Raman spectroscopy at different depths of 50, 100 and 150 microns was observed on $0^{\text {th }}, 5^{\text {th }}, 10^{\text {th }}$ and $15^{\text {th }}$ days of treatment and also all the variables was discrimi- 

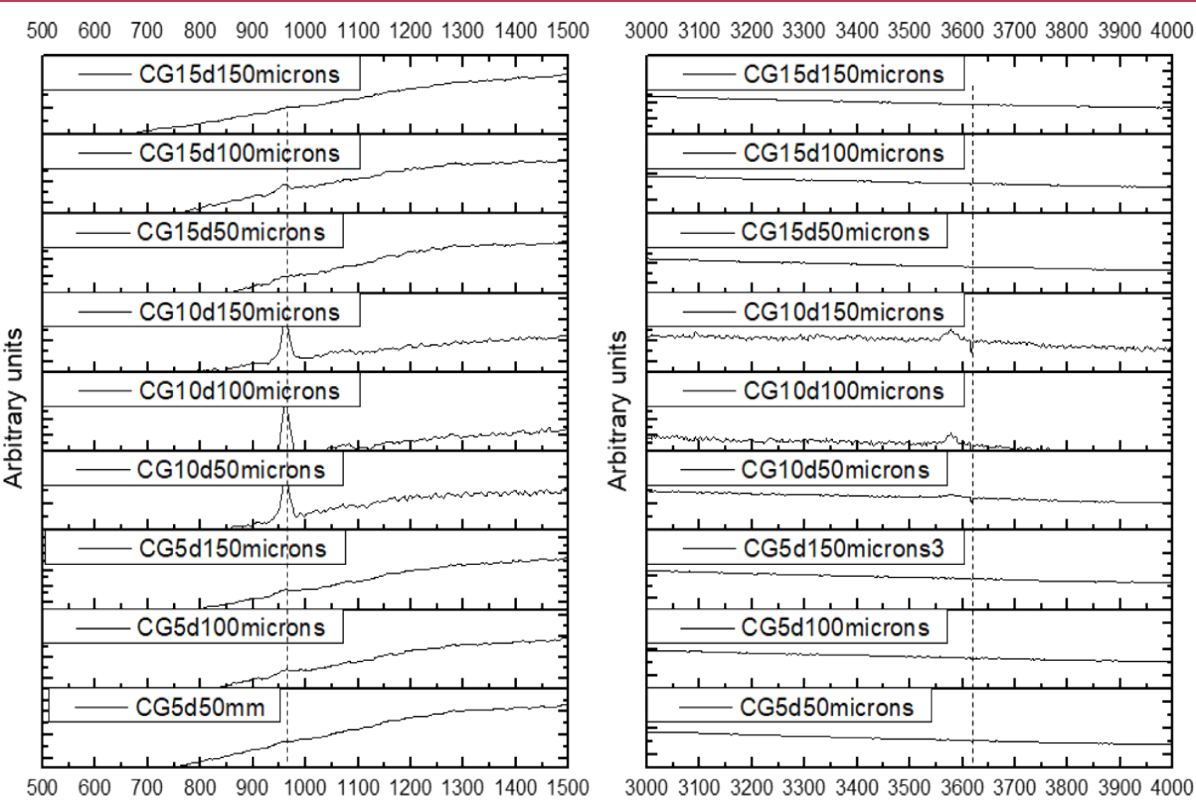

Figure 6: Representative spectra of the experimental group treated with Silver Diamine Fluoride (SDF) at $5^{\text {th }}, 10^{\text {th }}$ and $15^{\text {th }}$ days and at 50,100 and 150 microns deep (dentin enamel junction). The peaks due to $\mathrm{PO}_{4}^{3-}\left(970 \mathrm{~cm}^{-1}\right)$ and the $\mathrm{OH}^{-1}\left(3621 \mathrm{~cm}^{-1}\right)$ groups are observed.
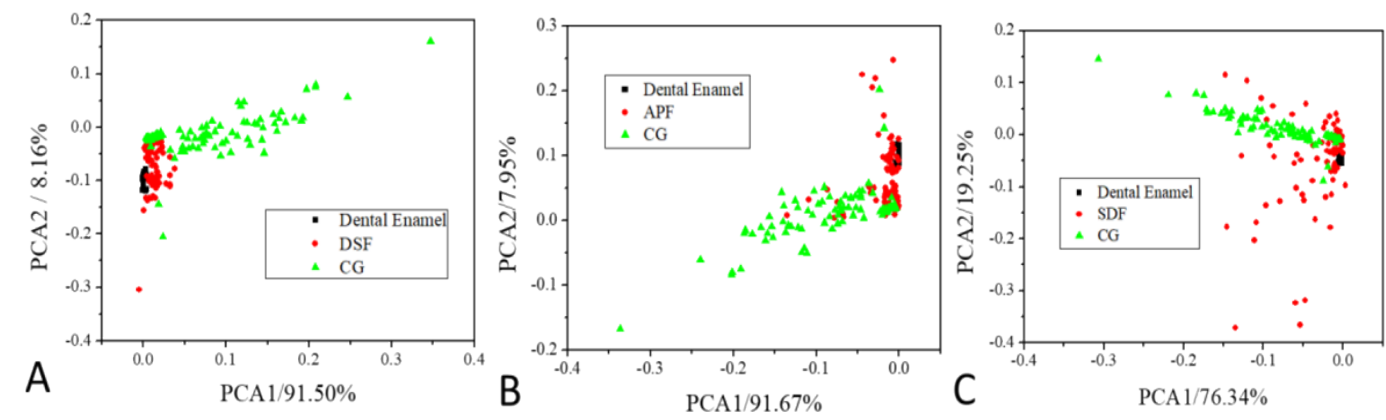

Figure 7: A) Dispersion of the group treated with Difluoride silane (DSF) where the distribution of observations was $91.7 \%$ when compared with the control group. B) Dispersion of the group treated with acidulated phosphate fluoride (APF) where the distribution of observations was (91.67\%) when compared with the control group. C) Dispersion of the group treated with SDF where the distribution of observations was (76.3\%) when compared with the control group.

nated because significant statistical differences were observed. In addition, it will always be better to apply any fluoride compound on the surfaces of tooth enamel, that is, varnishes, pastes, solutions, etc. not to apply something on the tooth enamel.

Shahabi et al., [37] carried out an in vitro Raman spectroscopic study of the carbonate anion concentration in tooth enamel after the application of in-office and home whitening agents. In this research, the effect on dental enamel was only evaluated with three fluorinated compounds and it was carried out because to date in the literature these fluorinated compounds have not been compared with the methodology presented here (different depths, different days, in the three different thirds enamel), in addition these fluorinated com- 
Raman Spectroscopy on Enamel Remineralized

pounds are the most used in pediatric dentistry.

A limitation of the present study is directed to the remineralizing effect of fluoride since concentrations of fluoride are used in the same state.

\section{Conclusion}

The APF and DSF have the effect of recovering the mineralization of dental enamel, except for the SDF. Functional groups $\mathrm{OH}^{-}$and $\mathrm{PO}_{4}^{3-}$ were identified in all subsurface.

The results of the present study showed that Raman spectroscopy and Principal Component Analysis (PCA) can be used to discriminate between healthy enamel, demineralized enamel and enamel remineralization with different fluoride solutions. The Raman-PCA technique can be an excellent non-invasive method to demonstrate qualitatively the early detection and monitoring of incipient lesions due to caries. In addition, the effect of the remineralization of the dental enamel can be observed.

\section{Conflict of Interest}

\section{None}

\section{References}

1. Sa Y, Feng X, Lei C, Yu Y, Jiang T, Wang Y. Evaluation of the effectiveness of micro-Raman spectroscopy in monitoring the mineral contents change of human enamel in vitro. Lasers Med Sci. 2017;32(5):985-91. doi: 10.1007/ s10103-017-2197-7. PubMed PMID: 28365815.

2. Tsuda H, Arends J. Raman Spectroscopy in Dental Research: A Short Review of Recent Studies. Advances in Dental Research. 1997;11(4):539-47. doi: 10.1177/08959374970110042301. PubMed PMID: 9470515.

3. Penel G, Leroy G, Rey C, Sombret B, Huvenne JP, Bres E. Infrared and Raman microspectrometry study of fluorfluor-hydroxy and hydroxy-apatite powders. Journal of Materials Science: Materials in Medicine. 1997;8(5):2716. doi: 10.1023/a:1018504126866.

4. Ten Cate JM, Damen JJM, Buijs MJ. Inhibition of Dentin Demineralization by Fluoride in vitro. Caries Research. 1998;32(2):141-7. doi: 10.1159/000016444. PMID: 9544863.

5. Ortega CCB, Tellez MAA, Perez AG. Assessment of Enamel Surface Microhardness with Different Fluorinated Compounds under pH Cycling Conditions: An in-
Vitro Study. Journal of Clinical and Diagnostic Research. 2019;13(8):5-10. doi: 10.7860/jcdr/2019/41054.13057.

6. Buchwald T, Okulus Z, Szybowicz M. Raman spectroscopy as a tool of early dental caries detection-new insights. Journal of Raman Spectroscopy. 2017;48(8):1094-102. doi: 10.1002/jrs.5175.

7. Akkus A, Yang S, Roperto R, Mustafa H, Teich S, Akkus 0 . A portable fiber-optic raman spectrometer concept for evaluation of mineral content within enamel tissue. J Clin Exp Dent. 2017;9(2):e238-41. doi: 10.4317/ jced.53185. PubMed PMID: 28210442. PubMed PMCID: PMCPMC5303324.

8. Ramakrishnaiah R, Rehman G, Basavarajappa D, et al. Applications of Raman Spectroscopy in Dentistry: Analysis of Tooth Structure. Journal Applied Spectroscopy Reviews. 2015;50(4):332-50. doi: 10.1080/05704928.2014.986734.

9. Shahabi S, Fekrazad R, Johari M, Chiniforoush N, Rezaei Y. FT-Raman spectroscopic characterization of enamel surfaces irradiated with Nd:YAG and Er:YAG lasers. Journal of Dental Research, Dental Clinics, Dental Prospects. 2016;10(4):207-12. doi: 10.15171/ joddd.2016.033. PubMed PMID: PMC5237666. PubMed PMCID: PMC5237666.

10. Jehlička J, Edwards HGM. Raman spectroscopy as a tool for the non-destructive identification of organic minerals in the geological record. Organic Geochemistry. 2008;39(4):371-86. doi: 10.1016/j.orggeochem.2008.01.005.

11. Mei ML, Chu CH, Lo ECM, Samaranayake LP. Fluoride and silver concentrations of silver diammine fluoride solutions for dental use. Int J Paediatr Dent. 2013;23(4):279-85. doi: 10.1111/ipd.12005. PubMed PMID: 23033939.

12. Pucéat E, Reynard B, Lécuyer C. Can crystallinity be used to determine the degree of chemical alteration of biogenic apatites? Chemical Geology. 2004;205(1):8397. doi: 10.1016/j.chemgeo.2003.12.014.

13. Rajendra A, Veitz-Keenan A, Oliveira BH, et al. Topical silver diamine fluoride for managing dental caries in children and adults. Cochrane Database of Systematic Reviews. 2017;2017(7):CD012718. doi: 10.1002/14651858. CD012718. PubMed PMCID: PMC6483208.

14. Beltrán-Aguilar ED, Goldstein JW, Lockwood SA. Fluoride Varnishes. A review of their clinical use, cariostatic mechanism, efficacy and safety. J Am Dent Assoc. 2000;131(5):589-96. doi: 10.14219/jada.archive.2000.0232. PubMed PMID: 10832252.

15. Marinho VCC, Worthington HV, Walsh T, Clarkson JE. Fluoride varnishes for preventing dental caries in children and adolescents. Cochrane Database of Systematic Reviews. 2013:CD002279. doi: 10.1002/14651858. CD002279.pub2. PubMed PMID: 23846772.

16. Trubman A, Crellin JA. Effect on Dental Caries of SelfApplication of Acidulated Phosphate Fluoride Paste and Gel. J Am Dent Assoc. 1973;86(1):153-7. doi: 10.1016/ 
s0002-8177(73)61038-0. PubMed PMID: 4404788.

17. Sato-Berrú RY, Mejía-Uriarte EV, Frausto-Reyes C, et al. Application of principal component analysis and Raman spectroscopy in the analysis of polycrystalline $\mathrm{BaTiO3}$ at high pressure. Spectrochimica Acta Part A: Molecular and Biomolecular Spectroscopy. 2007;66(3):55760. doi: 10.1016/j.saa.2006.03.032. PubMed PMID: 16859982.

18. Robinson C, Kirkham J, Baverstock AC, Shore RC. A Flexible and Rapid $\mathrm{pH}$ Cycling Procedure for Investigations into the Remineralisation and Demineralisation Behaviour of Human Enamel. Caries Research. 1992;26(1):147. doi: 10.1159/000261419. PubMed PMID: 1568232.

19. Ivancakova R, Hogan MM, Harless JD, Wefel JS. Effect of Fluoridated Milk on Progression of Root Surface Lesions in vitro under pH Cycling Conditions. Caries Research. 2003;37(3):166-71. doi: 10.1159/000070439. PubMed PMID: 12740538.

20. Ten Gate JM, Buijs MJ, Damen JJM. pH-cycling of enamel and dentin lesions in the presence of low concentrations of fluoride. European Journal of Oral Sciences. 1995;103(6):362-7. doi: 10.1111/j.1600-0722.1995. tb01858.x. PubMed PMID: 8747671.

21. Queiroz, Silva C, Hara, Takeo A, Leme P, et al. pHcycling models to evaluate the effect of low fluoride dentifrice on enamel de- and remineralization. Brazilian Dental Journal. 2008;19(1):21-7. doi: 10.1590/s010364402008000100004.

22. Tschoppe P, Zandim DL, Martus P, Kielbassa AM. Enamel and dentine remineralization by nano-hydroxyapatite toothpastes. Journal of Dentistry. 2011;39(6):430-7. doi: 10.1016/j.jdent.2011.03.008. PubMed PMID: 21504777

23. Itthagarun A, Wei SHY, Wefel JS. The effect of different commercial dentifrices on enamel lesion progression: an in vitro $\mathrm{pH}$-cycling study. International Dental Journal. 2000;50(1):21-8. doi: 10.1111/j.1875-595X.2000. tb00542.x. PubMed PMID: 10945176.

24. González-Solís JL, Martínez-Cano E, Magaña-López Y. Early detection of dental fluorosis using Raman spectroscopy and principal component analysis. Lasers in Medical Science. 2015;30(6):1675-81. doi: 10.1007/ s10103-014-1638-9. PubMed PMID: 25118662.

25. Cardenas AFM, Armas-Veja A, Rodriguez Villarreal JP, Siqueira FSFD, Muniz LP, Campos VS, et al. Influence of the mode of application of universal adhesive systems on adhesive properties to fluorotic enamel. Brazilian Oral Research. 2019. doi: 10.1590/1807-3107bor-2019. vol33.0120.

26. Arango-Santander S, Montoya C, Pelaez-Vargas A, Ossa EA. Chemical, structural and mechanical characterization of bovine enamel. Archives of Oral Biology. 2020;109:104573. doi: 10.1016/j.archoralbio.2019.104573. PubMed PMID: 31568993.

27. Mohamad Asri MN, Mat Desa WNS, Ismail D. Source Determination of Red Gel Pen Inks using Raman Spec- troscopy and Attenuated Total Reflectance Fourier Transform Infrared Spectroscopy combined with Pearson's Product Moment Correlation Coefficients and Principal Component Analysis. Journal of Forensic Sciences. 2018;63(1):285-91. doi:10.1111/1556-4029.13522.

28. Kinoshita H, Miyoshi N, Fukunaga Y, Ogawa T, Ogasawara T, Sano K. Functional mapping of carious enamel in human teeth with Raman microspectroscopy. Journal of Raman Spectroscopy. 2008;39(5):655-60. doi: 10.1002/jrs. 1908.

29. Vargas-Koudriavtsev T, Durán-Sedó R, Sáenz-Bonilla P, et al. Effect of tooth-bleaching agents on phosphate concentration in dental enamel by means of Raman spectroscopy. Revista Odontológica Mexicana. 2015;19(4):e22835. doi: 10.1016/j.rodmex.2015.10.013.

30. Naumova EA, Niemann N, Aretz L, Arnold WH. Effects of different amine fluoride concentrations on enamel remineralization. Journal of Dentistry. 2012;40(9):750-5. doi: 10.1016/j.jdent.2012.05.006. PubMed PMID: 22677913.

31. Ten Cate JM, Exterkate RAM, Buijs MJ. The relative efficacy of fluoride toothpastes assessed with pH cycling. Caries Res. 2006;40(2):136-41. doi: 10.1159/000091060. PubMed PMID: 16508271.

32. Yamazaki H, Litman A, Margolis HC. Effect of fluoride on artificial caries lesion progression and repair in human enamel: regulation of mineral deposition and dissolution under in vivo-like conditions. Arch Oral Biol. 2007;52(2):110-20. doi: 10.1016/j.archoralbio.2006.08.012. PubMed PMID: 17049334. PubMed PMCID: PMC2040327.

33. Seifo N, Al-yaseen W, Innes N. The efficacy of silver diamine fluoride in arresting caries in children. Evid Based Dent. 2018;19(2):42-3. doi: 10.1038/sj.ebd.6401301. PubMed PMID: 29930376.

34. Contreras V, Toro MJ, Elías-Boneta AR, EncarnaciónBurgos A. Effectiveness of silver diamine fluoride in caries prevention and arrest: a systematic literature review. General Dentistry. 2017;65(3):22-9. PubMed PMID: 28475081. PubMed PMCID: PMC5535266.

35. Yu OY, Zhao IS, Mei ML, Lo ECM, Chu CH. Cariesarresting effects of silver diamine fluoride and sodium fluoride on dentine caries lesions. Journal of Dentistry. 2018;78:65-71. doi: 10.1016/j.jdent.2018.08.007. PubMed PMID: 30114443.

36. Jardim JJ, Pagot MA, Maltz M. Artificial enamel dental caries treated with different topical fluoride regimes: An in situ study. Journal of Dentistry. 2008;36(6):396401. doi: 10.1016/j.jdent.2008.02.010. PubMed PMID: 18394771.

37. Shahabi S, Fekrazad R, Johari M, Chiniforoush N, Rezaei Y. FT-Raman spectroscopic characterization of enamel surfaces irradiated with Nd:YAG and Er:YAG lasers. J Dent Res Dent Clin Dent Prospects. 2016;10(4):20712. doi: 10.15171/joddd.2016.033. PubMed PMID: 28096945. PubMed PMCID: PMCPMC5237666. 